\title{
MODEL PENGEMBANGAN INDUSTRI HALAL FOOD DI INDONESIA
}

\author{
'Aang Yusril \\ Institut Agama Islam Riyadlotul Mujahidin Ngabar (IAIRM) Ponorogo \\ aangyusril@yahoo.com
}

\begin{abstract}
The development of the halal industry will become more competitive with the involvement of the financial industry and sharia banking sectors. This study aims to explore the role of sharia banking in the development of halal food industry in Indonesia. The research method used is descriptive qualitative method with literature review. Based on the results of the analysis, it can be concluded that the role of sharia banking is not only limited to shariah-based financing which is riba (interest), maysir (uncertainty), and gharar (gambling), but also at all stages of production process (halal value chain management). Sharia banks play important role that can use to develop and improve the halal food industry. First on the halal control stage, the second on the logistics process and the last stage of halal verification.
\end{abstract}

\section{Keywords: sharia bank; halal food industry; halal integrity}

\begin{abstract}
Abstrak
Pengembangan industri halal akan menjadi lebih kompetitif dengan keterlibatan dari sektor industri keuangan dan perbankan syariah. Penelitian ini bertujuan untuk mengeksplorasi peran perbankan syariah dalam pengembangan industri makanan halal di Indonesia. Metode penelitian yang digunakan adalah metode kualitatif deskriptif dengan telaah literatur. Berdasarkan hasil analisis, dapat disimpulkan bahwa peran perbankan syariah tidak hanya terbatas pada pembiayaan berbasis syariah yang bebas riba (bunga), maysir (ketidakpastian), dan gharar (perjudian). Akan tetapi juga pada seluruh tahapan proses produksi (halal value chain management). Peran penting yang dapat dilakukan perbankan syariah guna mengembangkan dan meningkatkan industri makanan halal, diantaranya dalam tiga proses halal integrity. Pertama pada tahap pengendalian halal, kedua pada proses logistik dan terkahir tahap halal verification.
\end{abstract}

Kata Kunci: perbankan syariah; industri makanan halal; halal integrity 


\section{PENDAHULUAN}

Industri halal mengalami perkembangan yang pesat dalam beberapa tahun ini. Gaya hidup halal yang identik dengan umat Muslim tersebar hingga ke berbagai negara, bahkan ke negara-negara dengan penduduk muslim minoritas. Halal menjadi indikator universal untuk jaminan kualitas produk dan standar hidup (Gillani, Ijaz, \& Khan, 2016). Halal biasanya hanya dikaitkan dengan hal-hal terkait kebendaan saja. Namun demikian, dalam Islam halal mencakup perbuatan dan pekerjaan atau biasa disebut dengan Muamalah (Qardhawi, 1993).

Halal dapat didefinisikan sebagai standar kualitas yang sesuai dengan hukum Shariah Islamiah dan digunakan pada setiap aktivitas yang dilakukan oleh umat Muslim (Bohari, Cheng, \& Fuad, 2013). Produk dan jasa halal dipilih oleh umat Muslim sebagai bentuk ketaatan terhadap hukum Shariah Islam. Meskipun halal sangat berkaitan dengan umat Muslim, bukan berarti konsumen produk halal hanya berasal dari umat Islam saja. Konsumen produk halal yang berasal dari negara dengan penduduk muslim minoritas mengalami peningkatan yang cukup signifikan dalam beberapa tahun belakangan. Salah satunya adalah Rusia yang berada di peringkat 9 sebagai konsumen makanan halal di dunia dengan capaian \$ 37 Miliar pada tahun 2015 (State of The Global Islamic Economy, 2016/2017). Kualitas produk halal, atau biasa dikenal dengan Halalan Thoyyiban, menjadi alasan umat non Muslim untuk menggunakan produk-produk halal (Samori, Salleh, \& Khalid, 2016) karena terdapat jaminan kebersihan, keamanan, dan kualitas produk untuk keseluruhan rantai produksi (from farm to plate).

Industri halal mengalami perkembangan pesat pada beberapa sektor antara lain: makanan halal, keuangan, travel, fashion, kosmetik dan obat-obatan, media dan hiburan, serta sektor lain seperti healthcaredan pendidikan. Laporan State of The Global Islamic Economy 2016/2017oleh Thomson Reuters, pada tabel 1, menunjukkan total pendapatan

yang diperoleh masing-masing sektor pada tahun 2015 beserta proyeksi pendapatan pada tahun 2021.

Tabel 1. Total Pendapatan dan Estimasi Pendapatan Industri Halal 


\begin{tabular}{|l|l|l|}
\hline \multicolumn{1}{|c|}{ SEKTOR } & \multicolumn{1}{|c|}{$\begin{array}{c}\text { TOTAL PENDAPATAN } \\
(2016)\end{array}$} & \multicolumn{1}{c|}{$\begin{array}{c}\text { ESTIMASI } \\
\text { PENDAPATAN (2020) }\end{array}$} \\
\hline $\begin{array}{l}\text { Makanan Halal } \\
\text { Keuangan }\end{array}$ & $\begin{array}{l}\text { \$1,17 Triliun } \\
\text { \$2 Triliun }\end{array}$ & $\begin{array}{l}\text { \$ 1,9 Triliun } \\
\text { \$ 3,5 Triliun } \\
\text { \$ 243 Miliar }\end{array}$ \\
Fashion & \$151 Miliar & \$ 368 Miliar \\
Obat dan kosmetik & \$243 Miliar & \$ 132 Miliar \\
Media dan hiburan & \$ 78 Miliar & \$262 Miliar \\
Healthcare & \$ 189 Miliar & \$ 565 Miliar \\
Pendidikan & \$ 436 Miliar & \$ 602 Miliar \\
\hline
\end{tabular}

Sumber: State of The Global Islamic Economy 2016/2017

Survei yang dilakukan di 76 negara yang terdiri dari 57 negara anggota Organisasi Konferensi Islam (OKI) dan 16 negara non OKI menunjukan bahwa sektor keuangan dan makanan halal memiliki kontribusi yang lebih besar dibandingkan dengan sektor yang lain. Dengan potensi pendapatan mencapai \$1,9 Triliun pada tahun 2021, industri makanan halal menjadi perhatian utama para pelaku usaha di berbagai negara, misalnya Malaysia. Pengembangan produk makanan halal menjadi fokus perhatian pemerintah Malaysia sehingga selama tiga tahun berturut-turut Malaysia berada di peringkat pertama untuk produsen makanan halal. Negara lain di kawasan Asia Tenggara yang mulai mengembangkan industri makanan halal adalah Thailand. Thailand mulai mengembangkan industri makanan halal meskipun bukan negara dengan mayoritas Muslim karena industri makanan halal memiliki prospek yang baik di masa yang akan datang.

Indonesia adalah negara dengan jumlah penduduk Muslim terbesar di dunia. Berdasarkan data Badan Pusat Statistik (BPS) pada tahun 2010 jumlah penduduk Indonesia mencapai 237,6 juta jiwa dengan populasi umat Muslim mencapai 207 jiwa atau sekitar 87 persen. Dengan jumlah penduduk muslim terbanyak di dunia, Indonesia memiliki potensi pasar yang besar bagi industri halal dunia. Laporan State of The Global Islamic Economy 2016/2017yang diterbitkan oleh Thomson Reuters menempatkan Indonesia di peringkat pertama untuk konsumen produk makanan halal yaitu sebesar $\$ 154,9$ Miliar. Namun 
demikian, pemerintah Indonesia belum dapat memaksimalkan potensi pasar tersebut karena Indonesia masih berada pada peringkat 10 untuk kategori produsen makanan halal.

Besarnya permintaan produk halal baik dari pasar domestik maupun luar negeri tidak diiringi dengan dukungan dari pemerintah Indonesia. Salah satu contohnya dalam hal sertifikasi produk halal. Seperti kebanyakan negara dengan penduduk Muslim mayoritas, badan sertifikasi halal kurang optimal karena adanya anggapan bahwa setiap produk makanan yang diproduksi di negara tersebut adalah halal sehingga tidak diperlukan sertifikasi halal pada produk tersebut (Gillani et al, 2016). Sertifikasi halal menjadi salah satu instrumen yang harus diperhatikan oleh pemerintah agar Indonesia mampu bersaing di industri halal. Selain itu, masih adanya pro dan kontra sertifikasi halal antara pemerintah dengan Lembaga Pengkajian Pangan, Obat-obatan, dan Kosmetika Majelis Ulama Indonesia (LPPOM MUI) menyebabkan proses sertifikasi halal saat ini belum optimal.

Berdasarkan data BPS, terdapat sekitar 57 juta Usaha Mikro Kecil dan Menengah (UMKM) di Indonesia dan yang telah memiliki sertifikat halal jumlahnya masih sangat sedikit. Berdasarkan data Majelis Ulama Indonesia (MUI) selaku lembaga yang berwenang mengeluarkan sertifikasi halal, pada periode 2014-2015 telah terbit sertifikat halal nasional untuk 6.231 perusahaan dan UMKM. Sedangkan untuk perusahaan yang berasal dari luar negeri, MUI telah menerbitkan sertifikat halal untuk 683 perusahaan yang artinya masih ada jutaan UMKM yang belum melaksanakan sertifikasi halal (Tirto, 2016). Oleh karena itu, pemerintah harus mampu memaksimalkan penerbitan sertifikat halal untuk UMKM guna meningkatkan pendapatan industri halal di Indonesia terutama dari sektor makanan halal.

Gillani et al. (2016) menyatakan bahwa bank syariah memainkan peran penting dalam mengembangkan UMKM. Bank syariah harus dapat memberikan produk-produk pembiayaan yang sesuai dengan kebutuhan, kompetitif, dan mudah diakses para pelaku UMKM yang bergerak di sektor makanan halal. Industri halal berkembang dalam tiga 
dimensi, dan bank syariah dapat memainkan peran untuk memaksimalkan ketiga hal tersebut, yaitu:

1. Pelaku UMKM seharusnya diberikan kesempatan yang lebih besar untuk membangun dan mengembangkan produk-produk halal.

2. Industri halal harus dipromosikan untuk dapat membangun kesadaran tentang pentingnya penggunaan produk jasa halal.

3. Gaya hidup halal harus lebih dikembangkan.

Perkembangan dan peningkatan perekonomian Indonesia di sektor industri makanan halal tidak akan dapat terlaksana tanpa adanya kerjasama antara berbagai pihak terkait. Oleh karena itu, perlu adanya integrasi peran pemerintah dan institusi keuangan syariah untuk meningkatkan daya saing UMKM dalam industri makanan halal. Penelitian ini bertujuan untuk mengeksplorasi peran perbankan syariah dalam pengembangan industri makanan halal di Indonesia. Penelitian ini penting karena mengkaji peran perbankan syariah secara komprehensif dalam halal integrityyang diwujudkan dalam setiap proses halal supply chain mulai dari pengendalian halal, logistik dan verifikasi halal. Sehingga diharapkan perbankan syariah dapat berperan secara optimal dalam meningkatkan pertumbuhan ekonomi Indonesia melalui pemberdayaan UMKM khususnya di sektor industri makanan halal.

Motivasi penelitian ini adalah tersedianya potensi pasar yang besar pada sektor industri makanan halal di Indonesia. Akan tetapi, belum terdapat langkah nyata yang diwujudkan dengan pengoptimalan peran oleh berbagai pihak terkait. Pengembangan industri halal akan menjadi lebih kompetitif dengan keterlibatan dari sektor industri keuangan dan perbankan syariah. Konsep pengembangan industri untuk produkproduk halal harus berjalan beriringan dengan perencanaan keuangannya. Dimulai dari aktivitas investasi, pelaku dalam industri halal harus memastikan bahwa usaha yang dilaksanakan sesuai dengan tuntunan shariah yang bebas dari unsur riba(bunga), maysir(ketidakpastian), dan gharar(perjudian) (Awang, Noor, Muhammad, Abdullah, Rahman, \& Yahya, 2016). Oleh karena itu, untuk dapat mencapai standar halal secara menyeluruh (holistic), 
diperlukan integrasi antara industri makanan halal dan industri keuangan syariah, baik perbankan syariah maupun institusi keuangan syariah lainnya.

\section{METODE PENELITIAN}

Penelitian ini merupakan penelitian kualitatif. Metode penelitian yang digunakan dalam penelitian ini adalah telaah literatur (literature review)dari berbagai penelitian yang telah dilakukan sebelumnya. Metode pengumpulan data yang digunakan yaitu data sekunder yang diperoleh dari jurnal, buku dokumentasi, dan internet. Diantaranya yaitu data-data yang dipublikasikan oleh lembaga-lembaga yang memiliki kredibilitas terpercaya, seperti data Otoritas Jasa Keuangan (OJK), Badan Pusat Statistik (BPS), dan Thomson Reuters.

Metode Analisis data dalam penelitian ini dilakukan dengan metode analisis deskriptif. Data-data yang sudah diperoleh kemudian dianalisis dengan metode analisis deskriptif. Metode analisis deskriptif dilakukan dengan menyusun data yang diperoleh kemudian diinterpretasikan dan dianalisis sehingga memberikan informasi bagi pemecahan masalah yang dihadapi.

\section{PEMBAHASAN}

Potensi Ekonomi Industri Makanan Halal Berdasarkan data Global Islamic Economy Reporttahun 2016-2017, Indonesia berada pada posisi 10 produsen industri halal secara global. Secara keseluruhan total pengeluaran dunia dalam industri halal mencapai US\$ 2,97 triliun. Sebesar US\$ 1,9 triliun atau setara dengan Rp 25.270 triliun merupakan sumbangan dari sektor makanan. Saat ini, Indonesia belum termasuk 10 besar produsen industri makanan halal. Produsen terbesar makanan halal didominasi oleh Malaysia.

Menurut Peneliti Bidang Ekonomi Islam, optimalisasi pengelolaan industri halal di dalam negeri mampu meningkatkan Anggaran Pendapatan dan Belanja Negara (APBN). Berdasarkan data yang ada, industri makanan halal memiliki pasar yang sangat besar. Berdasarkan data BPS, Indonesia memiliki penduduk muslim terbesar di dunia. Hal ini merupakan potensi ekonomi yang sangat besar. Sektor industri makanan halal merupakan 
potensi yang besar untuk dikembangkan. Rata-rata sektor industri diproyeksikan tumbuh sekitar delapan persen dalam kurun waktu hingga 2021. Dianalogikan jika Indonesia dapat menguasai 10 persen dari potensi industri makanan halal dunia yang mencapai $\mathrm{Rp} 25.270$ triliun, dipastikan penerimaan hanya dari industri makanan halal mencapai $\operatorname{Rp} 2.527$ triliun. Dengan demikian peningkatan sumber penerimaan negara akan semakin tinggi (Akbar, 2017).

Kementrian Perindustrian telah melakukan perencanaan untuk pembentukan kawasan industri halal yang ditargetkan selesai sebelum 2020. Hal tersebut dilakukan sebagai upaya respon atas peningkatan permintaan terhadap produk halal di dunia. Kawasan industri halal adalah kawasan industri yang di dalamnya semua industri menerapkan atau sesuai dengan standar Islam mulai dari hulu sampai hilir. Kawasan Industri Halal ini akan dipilih di wilayah Jawa karena sudah tersedia kawasan industri sektor consumer goods. Sedangkan pengelolaannya, pemerintah akan menyerahkan kepada salah satu pelaku usaha yang telah mengetahui standar-standar produksi halal yang baik (http://www.kemenperin.go.id).

\section{Halal Supply Chain}

Perkembangan pasar halal membutuhkan peningkatan efisiensi dalam pasar untuk dapat mengimbangi pertumbuhan tersebut. Salah satu pendekatan yang dapat digunakan adalah manajemen rantai persediaan (Supply Chain Management/SCM) (Noordin, Noor, \& Samicho, 2014). SCM dapat dimanfaatkan untuk meningkatkan produktifitas dan profitabilitas dari pasar halal (Noordin et al, 2014). Koordinasi yang stratejik dan sistemik dari fungsi-fungsi bisnis dalam sebuah perusahaan merupakan kunci keberhasilan penerapan SCM dalam perusahaan. SCM yang bersifat tradisional dapat didefinisikan sebagai proses pengkonversian bahan mentah menjadi barang jadi untuk selanjutnya didistribusikan sampai dengan konsumen akhir (Manzouri, AbRahman, Zain, \& Jamsari, 2014). Dalam perkembangan industri yang semakin pesat, terutama perkembangan industri halal, SCM yang bersifat tradisional dirasa tidak cukup mengakomodasi kebutuhan 
pasar. Oleh karena itu, SCM berkembang sesuai dengan kebutuhan industri menjadi halal supply chain.

Halal supply chaindapat didefinisikan sebagai integrasi proses dan aktivitas bisnis dari bahan baku sampai dengan konsumen akhir (from farm to plate) (Omar \& Jaafar, 2011). Jadi perbedaan antara SCM dan halal supply chainadalah tujuannya. Supply chain management (SCM)diterapkan di perusahaan supaya perusahaan dapat mengurangi biaya produksi. Di sisi lain halal supply chaindigunakan perusahaan dengan tujuan menjaga dan mempertahankan kehalalan produk (Gillani et al, 2016). Kehalalan produk yang tetap terjaga (halal integrity) akan menjadi salah satu keunggulan kompetitif bagi produsen untuk dapat bersaing dengan produsen lain di industri yang sama. Berikut ini adalah contoh gambar halal supply chainuntuk dapat menjaga kehalalan produk. Hanya spesies halal yang boleh dikembangbiakkan dan spesies halal tersebut tidak mengkonsumsi pakan yang haram (Soon, Chandia, \& Regenstein, 2017). 


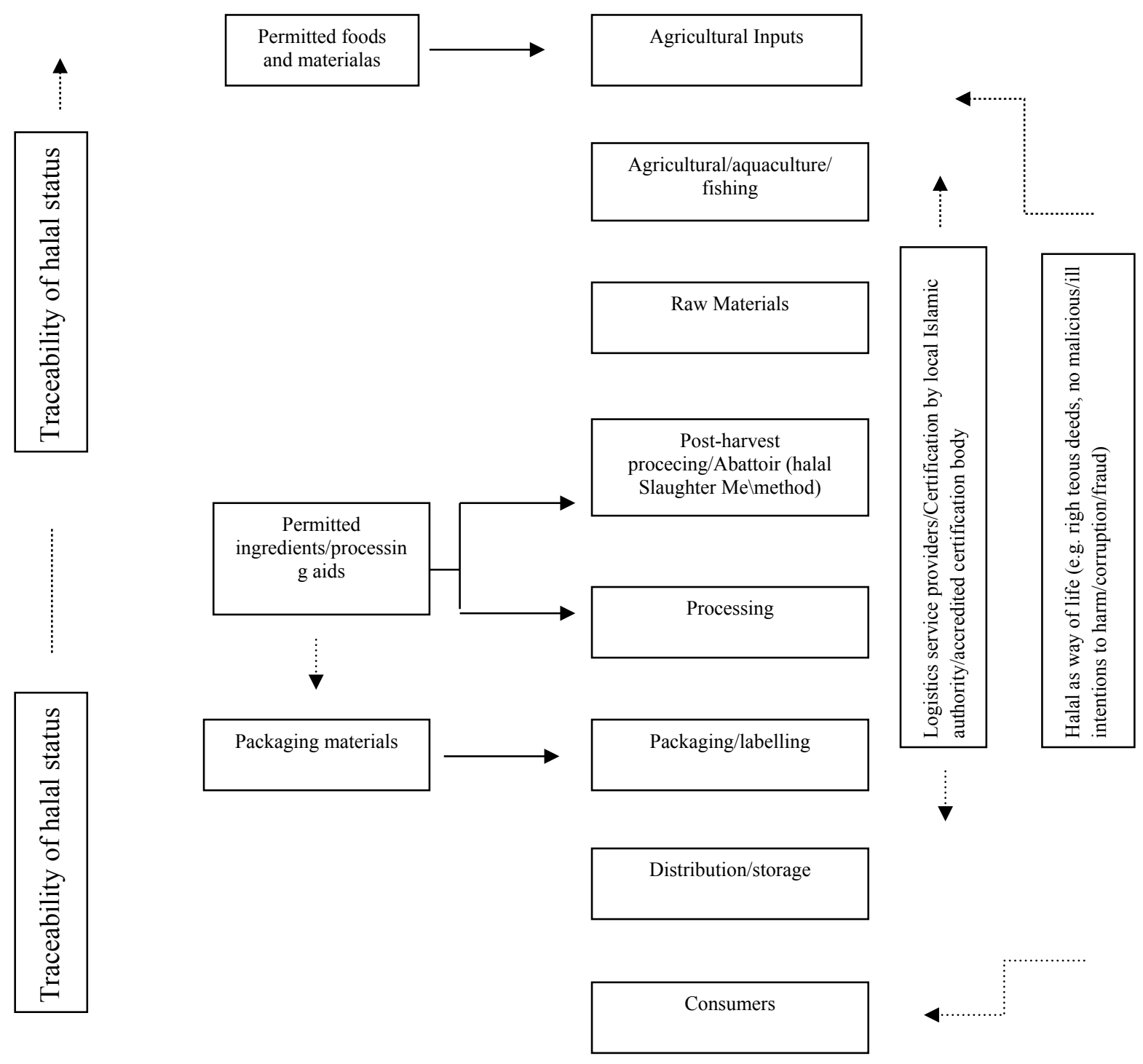

........ Covers the whole food chain (i.e.farm to fork)

$\longrightarrow$ Process flow

Sumber: (Soon, Chandia, \& Regenstein, 2017)

Gambar 1. Halal Integrity from Farm to Plate

Berdasarkan gambar 1, dapat disimpulkan bahwa halal integritydi setiap tingkatan proses produksi dan harus tetap menjadi prioritas utama dari pelaku usaha. Tahapan proses 
mulai dari bahan baku (input), proses setelah panen, pengemasan dan labelling, penyimpanan/ pendistribusian sampai ke tangan konsumen.

\section{Perencanaan Keuangan Islami}

Perencanaan keuangan yang Islami dapat didefinisikan sebagai proses mencapai tujuan melalui manajemen keuangan agar dapat meningkatkan, menciptakan, melindungi, memurnikan, dan mendistribusikan kekayaan atau modal sesuai dengan ketentuan Shariah Islam (Awang et al, 2016). Aturan-aturan dan prinsip-prinsip Shariah dimasukkan dalam proses perencanaan keuangan (Lahsasna, 2010). Lebih lanjut lagi Lahsasna (2010) mendefinisikan perencanaan keuangan Islami sebagai suatu proses menentukan tujuan dan prioritas keuangan serta sumber daya yang digunakan untuk dapat memperoleh hasil optimal, dengan Shariah Islam sebagai parameter utamanya.

Industri makanan halal tidak hanya berkaitan dengan produksi makanan halal saja tapi juga mencakup jasa keuangan syariah, yang melarang adanya bunga (riba), ketidakpastian (gharar), dan perjudian (maysir). Perencanaan keuangan Islami berperan penting dalam menyediakan dana dan peluang investasi terutama bagi pelaku UMKM. Berdasarkan data statistik perbankan syariah yang diterbitkan oleh OJK, pada bulan Maret 2017 pembiayaan dari Bank Umum Syariah dan Unit Usaha Syariah yang disalurkan kepada UMKM dalam bentuk modal kerja besarnya mencapai Rp 35.408 Miliar. Jumlah tersebut berada jauh di bawah total pembiayaan untuk non UMKM yang mencapai Rp 50.283 Miliar. Sedangkan pembiayaan dalam bentuk untuk investasi kepada UMKM oleh bank umum syariah dan unit usaha syariah hanya mencapai Rp 19.147 Miliar, dan untuk non UMKM mencapai Rp 41.167 Miliar. Oleh sebab itu pemerintah perlu membuat regulasi yang dapat meningkatkan pembiayaan bank syariah kepada pelaku UMKM.

\section{Halal Logistic}

Logistik dapat didefinisikan sebagai sebagai proses perencanaan, implementasi, dan pengendalian terkait proses penyimpanan barang dan jasa supaya dapat memenuhi kebutuhan dari pelanggan. Tujuan utama dari logistik adalah untuk memastikan bahwa 
konsumen dapat menikmati, menggunakan, atau mengkonsumsi produk pada waktu dan jumlah yang tepat, sesuai kebutuhan, serta dalam kondisi yang baik (Talib \& Hamid, 2013). Maka dapat disimpulkan bahwa manajemen logistik meliputi berbagai aktivitas, antara lain: transportasi, penyimpanan dan pergudangan, manajemen persediaan, pelayanan kepada konsumen, dan sebagainya.

Semua produk halal harus mengikuti hukum syariah, tidak terkecuali proses logistiknya. Oleh karena itu, perlu adanya proses logistik yang menerapkan prinsipprinsip syariah dalam pelaksanaannya. Prinsip utama dari halal logisticadalah memastikan pemisahan antara produk halal dan non halal. Dari seluruh supply chain, pihak penyedia jasa layanan logistik berperan penting untuk memastikan bahwa bahan mentah, bahan baku, pengemasan, penyimpanan dan trasnportasi produk halal telah dilakukan dengan benar sehingga tidak terkontaminasi produk non halal (Soon et al, 2017). Menurut Tieman (2013) ada tiga dasar dalam halal logistic, yaitu: kontak langsung dengan produk haram, risiko kontaminasi, dan persepsi konsumen Muslim. Ketiga hal tersebut penting untuk menjamin integritas kehalalan produk yang dihasilkan.

\section{Sertifikasi halal di Indonesia}

Sertifikasi halal adalah proses sertifikasi terhadap produk atau jasa sesuai dengan ketentuan syariah Islam. Sertifikasi halal dilakukan pertama kali di Amerika Serikat pada tahun 1960-an sebagai jaminan bagi umat Muslim yang tinggal di negara non Muslim agar dapat memenuhi kebutuhan sesuai dengan ketentuan agamanya. Halal merupakan persyaratan yang diwajibkan untuk setiap produk dan jasa yang dikonsumsi oleh umat Islam, dan saat ini dipertimbangkan sebagai standar kualitas produk. Standar kualitas halal diterapkan pada proses penyediaan dan produksi makanan, kosmetik, obat-obatan dan produk medis serta diterapkan pula pada pelayanan yang terkait dengan produk halal tersebut (Noordin et al, 2014).

Di Indonesia sertifikasi produk halal diberikan oleh Lembaga Pengkajian Pangan, Obat-obatan, dan Kosmetika Majelis Ulama Indonesia (LPPOM MUI). Masa berlaku

sertifikat halal tersebut adalah selama dua tahun. Selama periode tersebut, 
perusahaan/produsen harus mampu meyakinkan MUI dan konsumen bahwa tingkat kehalalan dari produk yang dihasilkan akan selalu dijaga. Oleh karena itu LPPOM MUI mewajibkan setiap perusahaan untuk membuat dan mendokumentasikan sistem jaminan halal(Halal Assurance System/HAS) sesuai dengan kebutuhan masing-masing perusahaan pada saat ingin mengajukan sertifikasi produk.

HAS adalah sistem yang disusun, diterapkan, dan dipelihara oleh perusahaan yang sudah memperoleh sertifikasi halal. HAS diperlukan oleh perusahaan untuk dapat mempertahankan kehalalan dari proses produksi sesuai dengan aturan dari LPPOM MUI. Prosedur pengajuan sertifikat halal oleh perusahaan ditunjukkan oleh Gambar 2.

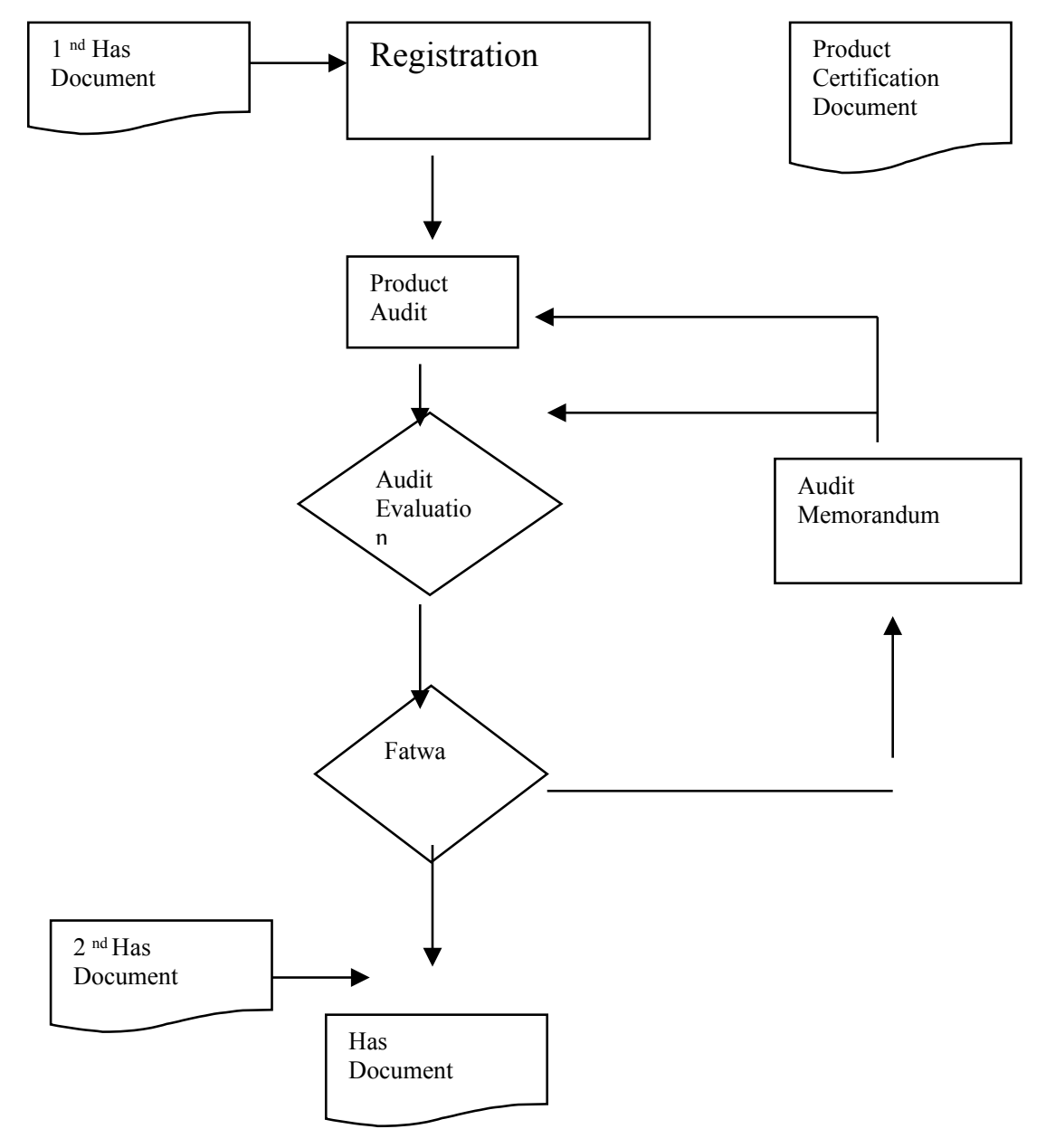

Sumber: General Guidelines of Halal Assurance System LPPOM (2008)

Gambar 2. Prosedur Sertifikasi Halal oleh LPPOM MUI 
Dari berbagai telaah literatur sebelumnya, dapat disimpulkan bahwa untuk dapat memaksimalkan pengembangan industri makanan halal di Indonesia, perlu adanya peran aktif dari institusi keuangan, khususnya perbankan syariah. Peran perbankan syariah sangat penting dalam halal integrity. Perbankan syariah dapat mengoptimalkan di setiap proses halal value chain yang terbagi dalam tiga tahapan yaitu pengendalian halal, logistik halal dan halal verification. Gambar 3 berikut merupakan penjabaran dari peran perbankan syariah sebagai upaya peningkatan industri makanan halal di Indonesia.

Peran Bank Syariah dalam Pengendalian Kehalalan Produk Produsen makanan harus memenuhi kebutuhan konsumen, baik konsumen non muslim maupun muslim. Kebutuhan untuk umat muslim yang utama adalah adanya jaminan halal terhadap produk-produk yang dikonsumsi. Salah satu indikator jaminan kehalalan produk adalah diperolehnya sertifikat halal dari LPPOM MUI oleh produsen makanan halal. Meskipun awalnya sertifikat halal hanya digunakan di negara-negara non Muslim untuk memenuhi kebutuhan warga muslim akan produk halal, saat ini sertifikasi halal dijadikan syarat utama untuk menjamin kualitas produk.

Sertifikasi halal di Indonesia saat ini, masih mengalami berbagai kendala. Tarik ulur antara pihak Majelis Ulama Indonesia (MUI) dan pemerintah (Kementerian Agama) tentang pihak yang lebih berhak untuk memberikan sertifikat halal masih terus berlangsung. Di Malaysia, pihak yang bertanggung jawab terkait pemberian sertifikat halal diberikan kepada pemerintah sehingga semua hal terkait dengan sertifikasi halal terpusat di pemerintah. Selain terkait lembaga pemberi sertifikat halal, penyebab masih sedikitnya produk atau perusahaan yang memiliki sertifikat halal MUI adalah karena ketidaktahuan para pelaku usaha terutama UMKM mengenai prosedur untuk mendapatkan sertifikat halal. Terlebih lagi banyak UMKM yang belum dikelola secara serius padahal memiliki prospek yang bagus di masa depan sehingga akan kesulitan pada saat pengajuan sertifikasi halal.

Panjangnya prosedur yang harus dilalui dan banyaknya dokumen yang harus dimiliki untuk dapat memperoleh sertifikat halal, menyebabkan para pengusaha UMKM tidak 
terlalu antusias dengan sertifikasi halal. Seperti kebanyakan negara dengan penduduk muslim yang besar, badan sertifikasi halal kurang optimal karena adanya anggapan bahwa setiap produk makanan yang diproduksi di negara tersebut adalah halal sehingga sertifikasi halal tidak terlalu diperlukan (Gillani et al, 2016). Dalam kondisi ini, perbankan syariah memiliki peran strategis mengembangkan industri halal melalui pemberdayaan UMKM.

\section{Peran Bank Syariah dalam Halal Logistic}

Logistik berperan penting dalam menjaga tingkat kehalalan suatu produk melalui sistem transportasi yang tepat, penyimpanan, dan penanganan produk sampai dengan tujuan akhir. Pemisahan antara produk halal dan non halal untuk mencegah terjadinya kontaminasi terhadap produk halal adalah kunci utama kesuksesan aktivitas halal logistic (Tan, Razali, \& Husny, 2013). Dalam hal ini perusahaan penyedia jasa halal logisticberperan penting menjaga integritas kehalalan produk.

Halal logistic yang dapat menjamin kehalalan produk, memerlukan pertimbangan beberapa faktor, antara lain: standar kebersihan (hygiene)yang komprehensif, kualitas dan juga keamanan produk. Pelayanan halal logisticmewajibkan prosedur khusus dalam penanganan rantai pasokan. Oleh karena itu perusahaan penyedia jasa layanan halal logistic harus mempertimbangkan beberapa hal penting (Jaafar, Endut, Faisol, \& Omar, 2011), diantaranya:

1. Penyedia jasa halal logistic harus memiliki pemahaman yang komprehensif tentang kehalalan produk serta dasar dan pedoman sebelum melakukan implementasi. Status halal akan diperoleh apabila seluruh aktivitas (SCM) telah diimplementasikan. Perusahaan dapat menerapkan standar penanganan produk untuk menjaga kehalalan produk. Apabila produk mengalami kontak langsung dengan produk non halal, maka produk halal tersebut menjadi produk non halal. Namun apabila produk non halal terbuat mengalami kontak dengan peralatan atau fasilitas penyimpanan dan pengiriman, maka bisa dilakukan prosedur penyucian sesuai dengan ketentuan Islam. 
2. Pemisahan produk halal dan non halal dapat dilakukan dengan berbagai cara, misalnya berdasarkan kompartemen, sistem pemeringkatan atau pengemasan yang tepat supaya produk halal dan non halal tidak bercampur. Prosedur penanganan juga harus diterapkan terhadap karyawan yang bertugas menangani produk, serta peralatan, mesin dan fasilitas yang digunakan.

3. Jaminan terhadap kehalalan produk bisa direalisasikan seandainya produk berada di bawah pengawasan perusahaan penyedia jasa halal logistic. Saat barang ditransfer ke perusahaan penyedia jasa halal logisticyang lain, maka kesempatan untuk tetap mempertahankan integritas kehalalan produk akan menurun. Situasi ini akan semakin memburuk pada level retailerkarena tingkat pengendalian dan pengawasan yang semakin menurun.

Tantangan yang dihadapi oleh industri halal ini dapat dijembatani oleh perbankan syariah. Pembinaan terhadap perusahaan penyedia jasa pelayanan halal logistic tentang pentingnya menjaga kehalalan produk harus dilakukan. Target awal yang harus dicapai adalah penyaluran produk dari mitra UMKM yang berada di bawah binaan bank syariah tersebut. Dengan demikian integritas kehalalan produk dapat dijamin karena seluruh proses produksi dan distribusi produk sampai dengan konsumen akhir berada dalam pengawasan bank syariah.

\section{Peran Bank Syariah dalam Halal Verification}

Halal verificationmerupakan tahap yang tidak kalah penting karena berkaitan dengan proses penyampaian produk jadi kepada konsumen akhir. Produk halal yg berkualitas tidak akan dapat mendatangkan keuntungan bagi produsen jika tidak dapat terjual ke konsumen. Hal yang seringkali terjadi adalah produk yang dihasilkan tidak selalu mendapatkan tanggapan baik dari konsumen meskipun produk yang dihasilkan sudah melalui proses produksi sesuai dengan ketentuan sistem jaminan halal bahkan memiliki sertifikat halal. Adanya anggapan di negara dengan penduduk Muslim mayoritas bahwa semua produk dianggap halal, menyebabkan sertifikasi halal tidak memiliki 
keunggulan kompetitif dibandingkan dengan produk lain yang belum memiliki sertifikat halal.

Edukasi terkait dengan produk halal perlu dilakukan. Masyarakat harus diberikan pemahaman bahwa mengonsumsi produk berlabel halal itu penting karena label halal pada produk makanan menjadi jaminan kehalalan produk. Salah satu cara yang bisa dilakukan adalah dengan mengkampanyekan gaya hidup halal. Memberikan pemahaman bahwa halal merupakan kebutuhan bukan hanya sekedar kewajiban yang harus dipenuhi. Peran yang dapat dimainkan oleh bank syariah dalam hal ini adalah mempromosikan UMKM halal yang berada di bawah binaannya. Bank syariah dapat mengalokasikan dana Corporate Social Responsibility (CSR)untuk mempromosikan produk-produk dari mitra mereka. Sarana promosi yang bisa digunakan ada bermacam-macam, misalnya dengan mengadakan bazar atau festival kuliner untuk produk halal. Selain bazar dan festival kuliner, promosi gaya hidup halal juga dapat dilakukan dengan acara talkshow maupun seminar. Konten acaranya bisa bermacam-macam, misalnya tentang pentingnya menggunakan produk halal, manfaat produk halal, serta cara untuk melakukan penelusuran produk halal. Dengan demikian peran bank syariah tidak berhenti pada proses produksi saja, namun juga pemasaran produk.

\section{KESIMPULAN}

Potensi pasar untuk industri makanan halal di Indonesia mengalami perkembangan pesat. Selama beberapa tahun terakhir, Indonesia berada di peringkat pertama sebagai konsumen makanan halal di dunia. Namun demikian, potensi pasar yang sangat besar tersebut belum mampu dimanfaatkan secara optimal oleh pemerintah untuk meningkatkan perekonomian Indonesia. Menjaga kualitas kehalalan produk makanan (halal integrity) merupakan salah satu cara agar dapat bersaing dengan negara lain dalam industri makanan halal. Peran perbankan syariah dalam pengembangan industri akanan halal perlu lebih dimaksimalkan.

Peran perbankan syariah tidak hanya terbatas pada pembiayaan berbasis syariah yang bebas riba(bunga), maysir(ketidakpastian), dan gharar(perjudian), tapi juga pada seluruh 
tahapan proses produksi (halal value chain management). Terdapat beberapa peran penting yang dapat dilakukan perbankan syariah guna mengembangkan dan meningkatkan industri makanan halal, diantaranya dalam tiga proses halal integrity. Pertama, pengendalian halal untuk memastikan proses produksi berjalan sesuai dengan standar jaminan halal yang sudah ditentukan. Poin penting yaitu produsen dapat menghasilkan produk makanan yang bersertifikat halal MUI. Kedua, halal logisticuntuk memastikan produk halal tidak terkontaminasi produk non halal pada saat proses distribusi. Ketigayaitu halal verificationyaitu peran bank syariah untuk mempromosikan gaya hidup halal, melakukan edukasi terhadap konsumen tentang pentingnya mengkonsumsi produk halal. Bahwa mengkonsumsi makanan halal bukan merupakan kewajiban namun kebutuhan yang harus dipenuhi oleh setiap umat manusia.

Adanya peran yang terintegrasi antara pemerintah, perbankan syariah, pelaku usaha, dan MUI diharapkan Indonesia dapat mewujudkan potensi ekonomi dengan menjadi pelaku di industri makanan halal. Perbankan syariah memiliki peran yang penting dalam pengelolaan industri secara tidak langsung yaitu melalui bantuan pembiayaan dan konsultan manajemen di setiap tahap proses halal integrity. Sebagai negara dengan penduduk muslim terbesar di dunia, Indonesia harus mulai berperan aktif. Bukan hanya menjadi konsumen, tetapi pelaku industri baik untuk pasar domestik maupun luar negeri. 


\section{DAFTAR PUSTAKA}

Akbar, R, J. (2017, Juli 26). Bukti Industri Halal Bisa Jadi Sumber Pendapatan Pemerintah. Vivanews. Diakses dari http://m.viva.co.id.

Awang, M. D., Noor, M. N., Muhammad , J., Abdullah, A., Rahman, S., \& Yahya, M. H. (2016). Acceptance and Application of Islamic Financial Planning among Small and Medium Enterprises Halal Operator in Peninsular of Malaysia. IJASOS- International EJournal of Advances in Social Sciences, 2 (6).

Bohari, A. M., Cheng, W. H., \& Fuad, N. (2013). An Analysis on the Competitiveness of Halal Food Industry in Malaysia: An Approach of SWOT and ICT Strategy. Malaysia Journal of Society and Space, 9 (1), 1-11.

Gillani, S. H., Ijaz, F., \& Khan, M. M. (2016). Role of Islamic Financial Institutions in Promotion of Pakistan Halal Food Industry. Islamic Banking and Finance Review,3 (1), 29-49.

Hidayat, R. (2016, Juli 11). Menjadi Penonton di Industri Halal. Tirto. Diakses dari https://tirto.id/.

Jaafar, H. S., Endut, I. R., Faisol, N., \& Omar, E. N. (2011). Innovation in Logistics Services - Halal Logistics. the 16th International Symposium on Logistics (ISL) (pp. 844-851). Berlin: ISBN: 978-085358-279-3.

Lahsasna, A. (2010). Understanding Shariah Financial Planning. Financial 1st Journal, January 2010 Issue, Malaysia Financial Planning Council, 40-41.

Lembaga Pengkajian Pangan, Obat-Obatan dan Kosmetika. (2008). General Guidelines of Halal Assurance System LPPOM Mui Majelis Ulama Indonesia (LPPOM MUI).

Manzouri, M., Ab-Rahman, M. N., Zain, C. R., \& Jamsari, E. A. (2014). Increasing Production and Eliminating Waste through Lean Tools and Techniques for Halal Food Companies. Sustainability, ISSN 2071-1050. 
Noordin, N., Noor, N. L., \& Samicho, Z. (2014). Strategic Approach to Halal Certification System: An Ecosystem Perspective. International Halal Conference, PWTC(pp. 79-95). Kuala Lumpur: Procedia - Social and Behavioral Sciences 121.

Omar, E. N., \& Jaafar, H. S. (2011). Halal Supply Chain in the Food Industry - A Conceptual Model. ISBEIA 2011 - 2011 IEEE Symposium on Business, Engineering and Industria Applications, (pp. 384-389). Langkawi.

Qardhawi, M. Y. (1993). Halal dan Haram dalam Islam.PT. Bina Ilmu.

Samori, Z., Salleh, N. Z., \& Khalid, M. M. (2016). Current Trends on Halal Tourism: Cases on Selected Asian Countries. Tourism Management Perspectives, 19, 131136.

Soon, J. M., Chandia, M., \& Regenstein, J. M. (2017). Halal Integrity in the Food Supply Chain. British Food Journal, 119 (1), 39-51.

Talib, M. S., \& Hamid, A. B. (2013). Halal Logistics in Malaysia: a SWOT Analysis. Jornal of Islamic Marketing.

Tan, M. I., Razali, R. N., \& Husny, Z. J. (2013). The Adoption of Halal Transportations Technologies for Halal Logistics Service Providers in Malaysia. International Journal of Mechanical, Aerospace, Industrial, Mechatronic and Manufacturing Engineering 6 (3).

Thomson Reuters. (2016). State of the Global Islamic Economic Report 2016/2017.

Tieman, M. (2013). Establishing The Principles In Halal Logistics. Journal of Emerging Economies and Islamic Research, 1 (1).

Internet: $w w w . k e m e n p e r i n . g o . i d$ 
